\title{
Genetic Diversity of Seed Storage Proteins of Rice (Oryza sativa L.) Varieties in Sri Lanka
}

\author{
L. Vithyashini and H.A.M. Wickramasinghe ${ }^{1 *}$ \\ Postgraduate Institute of Agriculture \\ University of Peradeniya \\ Sri Lanka
}

\begin{abstract}
ABSTRAC: Owing to a long history of rice cultivation and a rice improvement programme, Sri Lanka is home to a diverse range of rice germplasm. Characterization of germplasm is essential to provide information to the final users for the maximum utilization of a germplasm collection. Therefore, this study was carried out to assess the genetic diversity of rice (Oryza sativa L.) using seed storage proteins as a fingerprinting tool. A total of thirty two rice varieties including both traditional and newly improved varieties were subjected to seed protein extraction, followed by denatured-sodium dodecyl sulfate polyacrylamide gel electrophoresis (SDS-PAGE) and silver staining. Resultant gel showed a total of twelve bands consisting of four monomorphic and eight polymorphic bands. Protein quantification using Gel Quant.NET 1.6.6 software revealed the highest and the lowest protein levels in BW 272-6b and BG 360 respectively. Dendrogram obtained from both protein quantification and band binary scoring of SDS-PAGE profile clustered the seed storage protein-rich rice genotypes BW 272-6B, Pachchaperumal, Hondarawalu and Mawee into one group. A unique protein with a size of about $46 \mathrm{kDa}$ in BW 272-6, could be utilized as a protein molecular marker for its identification. The $133 \mathrm{kDa}$ protein present in BW 272-6B, Pachchaperumal and Hondarawalu could be used as an additional fingerprint in identification of these three varieties that are high in protein content. Therefore, this study suggests the use of protein profiling as a molecular tool for diversity exploration of rice genotypes using seed storage proteins.
\end{abstract}

Keywords: Cluster analysis, new improved rice varieties, SDS-PAGE, seed storage protein, traditional rice varieties.

\section{INRTODUCTION}

Rice is the most widely consumed staple food for a large part of the human population, especially those in Asia. Asian countries contribute to more than $90 \%$ of the world rice production and consumption (Muthayya et al., 2014). Rice is the single most important crop occupying 34\% of the total cultivated area in Sri Lanka. On average, 651,000 ha are cultivated during Maha and 313,000 ha during Yala, annually. About 1.8 million farmer families are engaged in paddy cultivation island-wide. Sri Lanka currently produces 3.3 million tonnes of rough rice annually and satisfies around $95 \%$ of the domestic demand (Central Bank of Sri Lanka, 2014; Department of Census and Statistics, 2015).

\footnotetext{
Department of Agricultural Biology, Faculty of Agriculture, University of Peradeniya, Peradeniya, Sri Lanka. * Corresponding author: mangalikaw@pdn.ac.lk
} 
Rice production in Sri Lanka is mainly depends on rainfall. Thus, the government needs to supply water through irrigation channels throughout the cultivation seasons. However, for the last few decades, drastic changes in climatic conditions highly affected the rice cultivation and production (Department of Census and Statistics, 2015) emphasizing the importance of breeding rice varieties adoptable for such adverse conditions. Furthermore, the rice consumption pattern has been changed due to consumer awareness on rice grain quality and the nutriceutical benefits of rice. Therefore, Abeywickrama et al. (2010) identified grain quality improvement as one of the major challenges for future rice breeding programs in Sri Lanka. Thus, selection of suitable rice varieties for farming, breeding programmes and consumption are the most crucial steps in current Sri Lankan rice industry to overcome biotic and abiotic stresses related issues of rice cultivation as well as socio economic concerns associated with rice farmers and consumers.

Characterization of germplasm is essential to provide information on different traits carried by each accession and this assures the maximum utilization of the germplasm collection by the end users (Ayres et al., 1997). Several strategies have been adopted for germplasm characterization including, morphological markers (Kancherla and Bhalla, 2003), cytological analysis (Bennici et al., 2004), biochemical analysis and molecular markers (Aggarwal et al., 1999; Rout et al., 2009). Among these numerous techniques available for assessing the genetic variability and relatedness among crop germplasm, seed storage protein analysis signifies a valid alternative improved approach via exploring the genetic diversity using sodium dodecyl sulphate-polyacrylamide gel electrophoresis (SDSPAGE) within a short period of time (Sadia et al., 2009; Netra and Prasad, 2007; Mennella et al., 1999). Seed storage protein markers are highly polymorphic and stable, and further the environmental influence on their electrophoretic pattern is low (Gepts et al., 1986; Sadia et al., 2009 and Galani et al., 2011). Therefore, the polymorphism of seed storage proteins has already been widely applied in plant classification (Portyanko et al., 1998), screening of mutants (Kumamaru et al., 1988), germplasm resource analysis ( $\mathrm{Yu}$ and Chen, 2003), variety identification (Song et al., 1996) and genetic diversity analysis (Yang et al., 2005).

In rice, seed storage protein profiling has already been used in analysis of diversity among ecotypes of japonica rice, and seed protein profiles have been shown to be useful in hybridity testing of a specific japonica hybrid (Wei-Dong et al., 2006). Further, it was used in analyzing inter-specific variation among wild rice (Shah et al., 2011) and purity testing of rice (Anitalakshmi et al., 2014). However, no study has been carried out to use seed storage protein profiles for the analysis of the genetic diversity or for any other application in Sri Lanka. Therefore, the present study was carried out to assess the genetic diversity in 30 Sri Lankan rice varieties including both traditional and new improved varieties using seed storage protein polymorphism.

\section{MATERIALS AND METHODS}

The present study was conducted at the Molecular Genetics laboratory, Department of Agricultural Biology, Faculty of Agriculture, University of Peradeniya, Sri Lanka. 


\section{Plant Material}

Total of 30 rice varieties including both traditional and improved varieties with two standard reference varieties namely, cultivar 93-11, Nipponbare, were grown at the Rice Research and Development Institute (RRDI), Batalegoda in the Maha season of 2013/2014 under similar management practices. Seeds were harvested and shade dried until the moisture content drops to $12-14 \%$. The details of rice varieties used in this study are given in Table 1.

Table 1. Rice varieties used for the analysis of seed storage proteins

\begin{tabular}{|c|c|}
\hline Name of the variety & Pericarp colour \\
\hline \multicolumn{2}{|l|}{ Improved rice varieties } \\
\hline Bg 360 & White \\
\hline $\mathrm{Bg} 366$ & White \\
\hline $\mathrm{Bg} 352$ & White \\
\hline Bg 358 & White \\
\hline Bg 94-1 & White \\
\hline At 306 & White \\
\hline At 405 & White \\
\hline Bw 267-3 & White \\
\hline Bw 272-6B & Red \\
\hline \multicolumn{2}{|l|}{ Traditional rice varieties } \\
\hline Gonabaru & White \\
\hline Suwandal & White \\
\hline Suduru samba & White \\
\hline Pacchaperumal & Red \\
\hline Hondarawalu & Red \\
\hline Pokkali & Red \\
\hline Wanni dahanala & Red \\
\hline Kalu heenati & Red \\
\hline Masuran & Red \\
\hline Kuruluthuda & Red \\
\hline Mawee & Red \\
\hline Iginimitiya & Red \\
\hline Madathawalu & Red \\
\hline Rathal & Red \\
\hline Kahatawee & Red \\
\hline Sudu heenati & Red \\
\hline Dular & Red \\
\hline Dikwee & Red \\
\hline Herathbanda & Red \\
\hline Sulai & Red \\
\hline Dewaraddari & Red \\
\hline \multicolumn{2}{|l|}{ Reference rice varieties } \\
\hline Nipponbare & Red \\
\hline
\end{tabular}




\section{Extraction of Rice Seed Storage Protein}

All extraction procedures were carried out from rice flour of de-hulled mature grains. To extract total proteins, $3 \mathrm{mg}$ of flour and $100 \mu \mathrm{L}$ of extraction buffer $(0.055 \mathrm{M}$ Tris-HCl pH-6.8, 2.3\% SDS, 5\% $\beta$-mercaptoethanol, 10\% Glycerol and 0.1\% Bromo phenol blue) was added and allowed to boil for $10 \mathrm{~min}$. Then, the samples were kept for $4-5 \mathrm{~h}$ at room temperature and were centrifuged at $12,000 \mathrm{rpm}$ for $10 \mathrm{~min}$ at $4^{\circ} \mathrm{C}$, in order to collect total soluble proteins as the supernatant.

\section{Protein Profiling}

Protein profiling of extracted samples were analyzed through SDS-PAGE (Laemmli, 1970) in a discontinuous buffer system with a 5\% stacking gel and a 15\% resolving gel (30:0.135 acylamide: BIS). The extracted proteins $(10 \mu \mathrm{L})$ were loaded along with a protein marker (Promega- V849a) and the gel was subjected to electrophoresis (AF 6200, Atto Corporation, Japan) at $30 \mathrm{~mA}$ using Tris-glycine buffer for $3 \mathrm{~h}$.

\section{Silver Staining}

Gel was kept in fixing solution (12.5\% acetic acid, 37.5\% ethanol) for a period of $15 \mathrm{~min}$, followed by $20 \%$ ethanol and was washed with distilled water three times. Then, the gel was subjected to sensitization using $0.02 \%$ sodium thiosulfate for $10 \mathrm{~min}$ followed by three washes using distilled water. For staining, $0.2 \%$ silver nitrate was added and the gels were stained for $45 \mathrm{~min}$. The gels were then placed in a developing solution $(3 \% \mathrm{~K} 2 \mathrm{CO} 3,0.001 \%$ $\mathrm{Na} 2 \mathrm{~S} 2 \mathrm{O} 3,0.024 \%$ formaldehyde) until the bands were prominently visible. Then the gels were immediately placed in a fixation solution (5\% Tris base, $2.5 \%$ acetic acid) with continuous mild shaking for about 5 min and finally the gels were rinsed with distilled water and were visualized.

\section{Protein Imaging and Data Analysis}

Silver stained gels were visualized under white light and were photographed. The image was subjected to protein on-gel quantification using Gel Quant.NET 1.6.6 software (volume basis). Further, the banding profiles were viewed and compared with the protein ladder. Clear and unambiguous bands were identified by using My Image Analysis v2.0 Software. A cluster analysis was performed for both on-gel quantified seed protein as well as for the clear and unambiguous banding profile in binary score basis using SAS 9.1.3 portable software.

\section{RESULTS AND DISCUSSION}

In this study, SDS-PAGE profiling of seed proteins of thirty two rice genotypes were carried out to investigate the genetic diversity. Based on the on-gel quantification of proteins, the least quantity of proteins was shown by $\mathrm{Bg} 360$ while the highest quantity was from $\mathrm{Bw}$ 272-6B. Except for $\mathrm{Bw} 272-6 \mathrm{~B}$ and $\mathrm{Bw} 267-3$, relatively lower protein 
content was shown by other improved varieties than that in the traditional varieties (data not shown). A cluster analysis was done for on-gel quantified extracted seed storage protein and the dendrogram obtained is shown in Fig.1.

Three prominent clusters were observed based on the quantity of grain reserve protein. The smaller cluster consisting four rice varieties viz $\mathrm{Bw}$ 272-6B, Pachchaperumal, Hondarawalu, Mawee were clearly separated from the rest of the varieties tested at an average genetic distance of 1.5 , and they all showed a high protein content. Two other large clusters; one containing seventeen rice varieties viz Bg 360, Bg 358, Inginimitiya, Bg 352, Bg 366, Nipponbare, Gonabaru, Suwandal, At 405, At 306, Bw 267-3, Dikwee, Rathal, Suduru samba, Sulai, Cultivar 93-11, Bg 94-1 and the other having eleven rice varieties viz Pokkali, Wanni dahanala, Masuran, Kaluheenati, Dular, Madathawalu, Kuruluthuda, Kahata wee, Sudu heenati, Dewaraddiri, Herath banda were clearly separated at an average genetic distance of 1.0. Further, several minor clusters were shown around or less than 0.5 of average genetic distance (Fig. 1). Though on-gel protein quantification discriminated the tested rice varieties to many clusters, suitability of the technique for variety identification is doubtful due to poor reproducibility. A considerable variation was observed in protein quantities obtained from each replication.

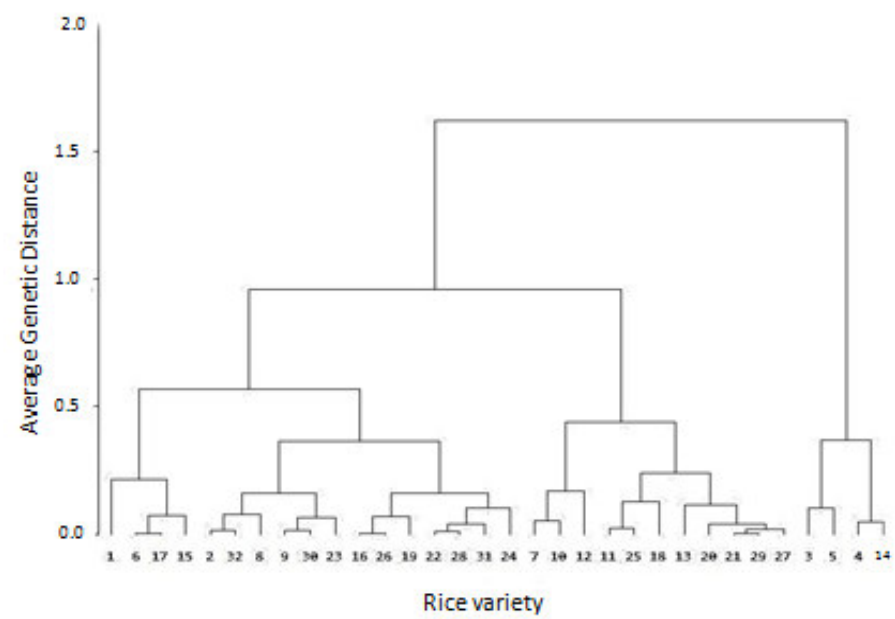

Fig. 1. Clustering of rice varieties based on on-gel quantification of seed storage protein.

1-Bg 360, 2- Bg 366, 3- Bw 272-6B, 4- Pacchaperumal, 5- Hodarawalu, 6- Bg 358, 7- Pokkali, 8- Gonabaru, 9- Suwandal, 10- Wanni dahanala, 11- Kaluheenati, 12- Masuran, 13- Kuruluthuda, 15- Bg 352, 16- Bw 267-3, 17- Iginimitiya, 18-Madathawulu, 19- Rathal, 20- Kahata wee, 21- Sudu heenati, 22- Suduru samba, 23- At 306, 24- Bg 94-1, 25-Dular, 26- Dikwee, 27- Herath banda, 28- Sulai, 29- Dewaraddari, 30- At 405, 31- Cultivar 93-11, 32- Nipponbare

It is a proven fact that the protein content and the protein quality of rice grains varied significantly (Shewry and Halford, 2002: Kush, 1989). Eventhough we could not compare the total protein content of selected rice varieties due to unavailability of such data for each variety tested, the diversity shown by soluble proteins extracted in this study would be representing their total protein diversity. Shotwell and Larkins (1989) showed that the total storage protein content in $O$. sativa endosperm varied between 4.3 and $18.2 \%$ and was divided into four fractions according to their differences in solubility viz albumins (soluble 
in water), globulins (soluble in salts), prolamin (soluble in alcohol), and glutelin (soluble in acidic or basic solutions).

The protein banding profile of each variety looked similar in all the genotypes though the intensity of the appeared bands were not uniform. A representative gel profile is given in Fig. 2. However, based on the analysis using My Image Analysis v2.0 software, twelve clear and unambiguous bands were elected consist with four monomorphic and eight polymorphic bands. Jiang et al. (2014) found about 34 protein bands from rice seeds. Proteins are highly heterogeneous in their solubility related properties in different buffers. Therefore, the less number of protein bands observed in the present study would be due to differences in the buffers and techniques used for the extraction.

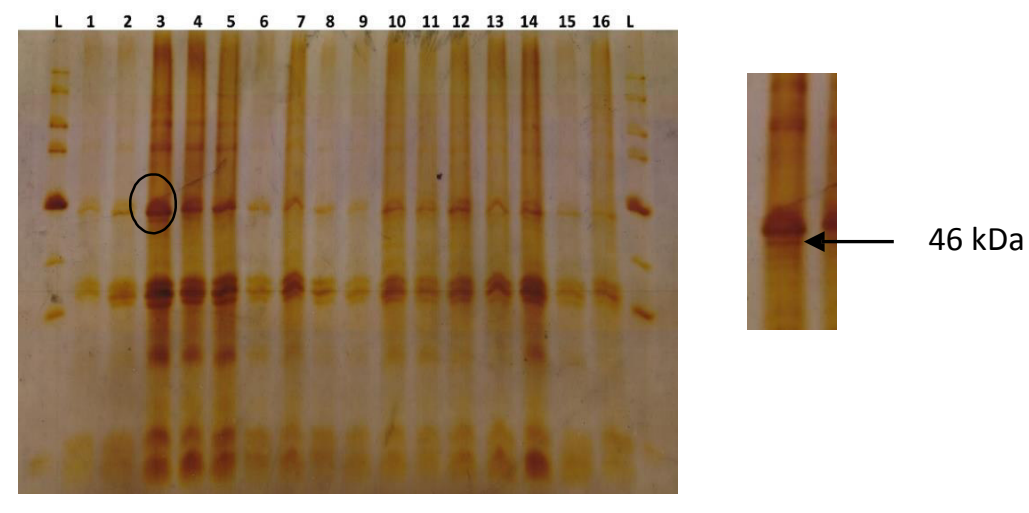

Fig. 2. Polyacylamide gel electrophoresis pattern of total soluble seed storage
proteins of selected rice varieties in Sri Lanka

Genotype Id 1-16; Bg 360, Bg 366, Bw 272-6B, Pachchaperumal, Hondarawalu, Bg 358, Pokkali, Gonabaru, Suwadal, Wanni Dahanala, Kaluheenati, Masuran, Kuruluthudu, Mawee, Bg 352, Bw 267-3, respectively. L- protein marker.

With the aid of the protein marker, size of the each band was determined. All 32 rice varieties showed monomorphic protein bands with approximate sizes of $32 \mathrm{kDa}, 30 \mathrm{kDa}$, $14 \mathrm{kDa}$ and $10 \mathrm{kDa}$ and polymorphic protein bands with approximate sizes of $133 \mathrm{KDa}$, $100 \mathrm{kDa}, 75 \mathrm{kDa}, 50 \mathrm{kDa}, 46 \mathrm{KDa}, 26 \mathrm{kDa}, 21 \mathrm{kDa}, 13 \mathrm{kDa}$. Among the 8 polymorphic protein bands, the protein band with approximate size of $46 \mathrm{kDa}$ was unique to variety $\mathrm{Bw}$ 272-6B. Therefore, this unique protein band could be a suitable protein marker in the identification of rice varietiy Bw 272-6B. Galani et al. (2011) found that $46 \mathrm{kDa}$ unique band from Kanwal-95 out of ten elite rice genotypes of Sindh, Pakistan indicating the possible use of protein profiles in analyzing relationship among genotypes across countries. Among the polymorphic protein bands, $133 \mathrm{kDa}$ protein band was detected only in $\mathrm{Bw} 272$ 6B, Pachchaperumal and Hondarawalu indicating the possible use of $133 \mathrm{kDa}$ protein bands as markers in identification of Bw 272-6B Pachchaperumal and Hondarawalu, the genotypes that showed the highest amounts of seed storage protein among all 32 rice varieties.

The protein bands with approximate sizes of $100 \mathrm{kDa}, 75 \mathrm{kDa}$ and $21 \mathrm{kDa}$ were highly polymorphic compared to the other proteins observed. Therefore, these bands would be 
suitable in diversity analysis in rice varieties. The protein band with approximate size of 13 $\mathrm{kDa}$ was found in all varieties tested except the rice variety Madathawulu. Furthermore, the protein band with the approximate size of $25 \mathrm{kDa}$ was also absent only in $\mathrm{Bg} \mathrm{360.} \mathrm{The}$ protein band of about $50 \mathrm{kDa}$ was absent only in rice varieties At 306, At 405 and Iginimitiya. Therefore, protein bands with approximate sizes of $13 \mathrm{kDa}, 25 \mathrm{kDa}$ and $50 \mathrm{kDa}$ could be suitable for discriminating the rice varieties Madathawulu, $\mathrm{Bg} 360$, At 306, At 405 and Iginimitiya from rest of the varieties tested.

Protein bands with sizes of $10 \mathrm{kDa}, 13 \mathrm{kDa}$, and $22-23 \mathrm{kDa}$ were already identified by Jugran et al. (2010) as albumin, prolamin, glutelin and $\beta$-subunits, respectively, and were successfully used in characterization of agro- diversity of forty eight rice germplasm from Uttarakhand Himalaya, India. Among those, glutelin fraction was considered as the predominant protein in the rice endosperm (Katsude- Tanaka et al., 2004). Since the protocol used in this study was mainly focused on extraction of total water soluble proteins, availability of poly peptide diversity may become law.

In order to find out the diversity among rice varieties, scored data matrix based on band profile was subjected to cluster analysis. Similarity matrix of the resulted dendrogram (Fig. 3 ) revealed that there were three groups containing $22 \% 66 \%$ and $12 \%$ of the total number of varieties tested. Rice varieties Bw 272-6B, Pachchaperumal, Hondarawalu and Mawee which were grouped together based on on-gel protein content, grouped again to a small cluster based on the protein banding profile too, confirming the results obtained.

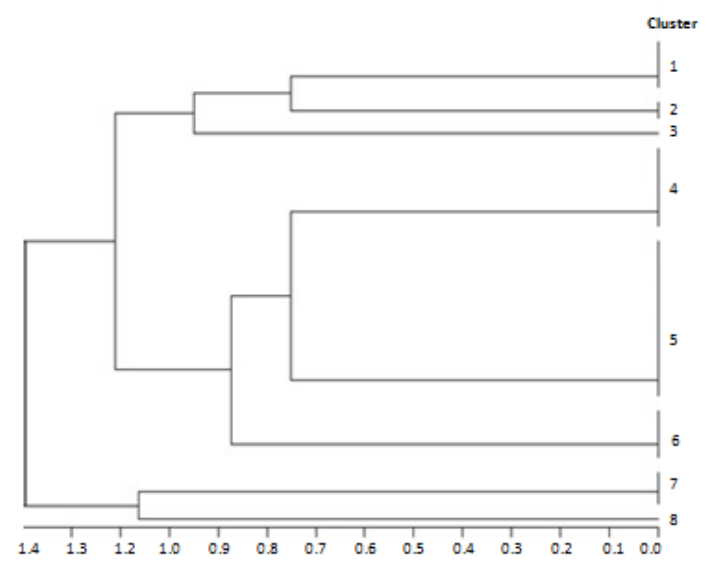

Fig. 3. The relationship of rice varieties based on the grain reserve protein profiles.

Cluster 1: Bg 360, Bg 366, Mawee, Bw 267-3; Cluster 2 : Pacchaperumal, Hodarawalu; Cluster 3:Bw 2726B; Cluster 4: BG 358, Pokkali, Wanni dahanala, Kalu heenati, Masuran, Kuruluthuda; Cluster 5: Gonabaru, Suwandal, Bg 352, Rathal, , Suduru samba, Bg 94-1, Dular, Sulai, Dewaraddari, Cultivar 93-11, Nipponbare; Cluster 6: Kahata wee, Sudu heenati, Dikwee, Herath banda; Cluster 7: Iginimitiya, At 306, At 405; Cluster 8: Madathawulu

Previous studies indicate that the glutelin and prolamin content is a good indicator of high protein content in rice and account for $80 \%-85 \%$ of the total seed protein (Takaiwa et al., 1999) and glutelin is also identified as easily digestible protein comprises of high amount of essential amino acids (Ogawa et al., 1987; Resurreccion et al., 1993). As common 
storage proteins, glutelin and prolamin were observed in all 32 rice varieties. Further studies are needed to explain the total glutelin and prolamin contents, their diversities in isoforms, and also the amino acids composition.

\section{CONCLUSIONS}

Comparative analysis of protein profile can result a considerable level of polymorphism in a panel rice varieties and thus, this technique can be effectively used as a tool for characterization or identification of Sri Lankan rice varieties. A protein band with approximate size of $46 \mathrm{kDa}$ was unique to rice variety $\mathrm{Bw} 272-6 \mathrm{~B}$ and therefore, could be used as a protein marker in identification of the above rice varieties. The $133 \mathrm{kDa}$ protein present in Bw 272-6B, Pachchaperumal and Hondarawalu could be used as an additional fingerprint in the identification of these three varieties that are high in protein content. Furthermore, protein bands with approximate sizes of $13 \mathrm{kDa}, 25 \mathrm{kDa}$ and $50 \mathrm{kDa}$ could be suitable for discriminating the rice varieties Madathawulu, Bg 360, At 306, At 405 and Iginimitiya from rest of the varieties tested. On-gel quantification of protein could also be improved further in analyzing genetic diversities in rice seed storage proteins.

\section{ACKNOWLEDGEMENTS}

The financial assistance provided by National Research Council through the research grant NRC-11-86 is greatly acknowledged.

\section{REFERENCES}

Abeywickrama, A.S.M.T., Gunadasa, A.H., Abeysekara, S.W., Hemachandra, P.V. and Pathinayake, B.D. (2010). Rice variety improvement in Sri Lanka: progress achieved and vision for the future. Rice Congress at Plant Genetic Resources Center, Gannoruwa, Sri Lanka. 2-3 December, 2010. Pp: 9.

Aggarwal, R.K., Brar, D.S., Nandi, S., Huang, N. and Khush, G.S. (1999). Phylogenetic relationships among Oryza species revealed by AFLP markers. Theor. Appl. Genet. 98, 1320 $-1328$.

Anitalakshmi, V., Gowda, R., Sathisha, C.S. and Hittalmani, S. (2014). Characterization of cultivars based on electrophoretic analysis of seed proteins, isozymes and DNA markers in rice(Oryza sativa L.). Indian J. Plant Sci. 3: 180-181. Accessed online http://www.cibtech.org/jps.htm

Ayres, N.M., McClung, A.M., Larkin, P.D., Bligh, H.F.J., Jones, C.A. and Park, W.D. (1997). Microsatellite and single nucleotide polymorphism differentiate apparent amylose classes in an extended pedigree of US rice germplasm. Theor. Appl. Genet. 94, 773 - 781.

Bennici, A., Anzidei, M., and Vendramin, G.G. (2004). Genetic stability and uniformity of Foeniculum vulgare Mill. regenerated plants through organogenesis and somatic embryogenesis. Plant Sci. 166(1), 221 - 227. 
Central Bank of Sri Lanka (2014). Annual Report, Central Bank of Sri Lanka [online]. [Accessed on 11.06.2015]. Available at http://www.cbsl.gov.lk/pics_n_docs/10_pub/_docs/efr/annual_report/AR2014/English/17_ App endix.pdf.

Department of Census and Statistics (2015). Agriculture and Environment Statistic Division, Department of Census and Statistics [on line]. [Accessed on 11.06.2015]. Available at http://www.statistics.gov.lk/agriculture/.

Galani, S., Naz, F., Soomro, F., Jamil, I., Hassan, Z., Azhar, A. and Ashraf, A. (2011). Seed storage protein polymorphism in ten elite rice (Oryza sativa L.) genotypes of Sindh. African J. Biotechnol. 10(7), 1106 - 1111

Gepts, P., Osborne, T.C., Rashka, K., Bliss, F.A. (1986). Phaseoline protein of wild form variability in and landraces of the common beans (Phaseolus vulgare): Evidence for multiple centers of domestication. Econ. Bot. 40, 451 - 468.

Jiang, C., Cheng, Z., Zhang, C., Yu, T., Zhong, Q., Shen, J.Q. and Huang, X. (2014). Proteomic analysis of seed storage proteins in wild rice species of the Oryza genus. Proteome Sci. 12:51 Accessed on http://www.proteomesci.com/content/12/1/51

Jugran, A., Bhatt, I.D. and Rawal, R.S. (2010). Characterization of agro-diversity by seed storage protein electrophoresis: focus on rice germplasm from Uttarakhand Himalaya, India. Rice Sci. 17(2), 122 - 128.

Laemmli, U.K. (1970). Cleavage of structural proteins during the assembly of the head of bacteriophage T4. Nature, 227, 680 - 685 .

Kancherla, L.S., and Bhalla, P.M. (2003). Phenotypic variations in micropropagated Australian ornamental climber Pandorea pandorana. Acta Hort. 616, 463 - 466.

Katsude-Tanaka, T., Duldulao, J.B.A., Kimura,Y., Iida, S., Yamaguchi, T., Nakano, J., Utsumi, S. (2004). The two subfamilies of rice glutelin differ in both primary and higherorder structures. Biochimica et Biophysica Acta, 1699, 95 - 102.

Kumamaru, T., Satoh, H., Iwata, N., Omura, T., Ogawa, M. and Tanaka, K. (1988). Mutants for rice storage proteins:I. Screening of mutants for rice storage proteins of protein bodies in the starchy endosperm. Theor Appl Genet.76, 11 - 16.

Khush, G.S. (1997). Origin, dispersal, cultivation and variation of rice. Plant Mol. Biol. 35, $25-34$.

Mennella, G., Onofaro, S.V., Tonini, A. and Magnifico, V. (1999). Seed storage protein characterization of Solanum specie and of cultivars and androgenic lines of S. melongena L., by SDS-PAGE and AE-HPLC. Seed Sci. Technol. 27, 23 - 35.

Muthayya,S., Sugimoto,J.D., Montgomery, S. and Maberly, G.F. (2014). An overview of global rice production, supply, trade, and consumption. Ann. N.Y. Acad. Sci. 1324, 7-14. Accessed on http://onlinelibrary.wiley.com/doi/10.1111/nyas.12540/pdf 
Netra, N. and Prasad, S. (2007). Identification of rice hybrids and their parental lines based on seed, seedling characters, chemical tests and gel electrophoresis of total soluble seed proteins. Seed Sci. Technol. 35, 176 - 186.

Ogawa, M., Kumamaru, T., Satoh, H., Iwata, N., Omura, T., Kasai, Z. and Tanaka, K. (1987). Purification of protein body-I of rice seed and its polypeptide composition. Plant Cell Physiol. 28, 1517 - 1527.

Portyanko, V.A., Sharopova, N.R. and Sozinov, A.A. (1998). Characterization of European oat germplasm: allelic variation at complex avenin loci detected by acid polyacrylamide gel electrophoresis. Euphytica.102, 15 - 27.

Resurreccion, A.P., Li, X. and Okita, T.W. (1993). Characterization of poorly digested protein of cooked rice bodies. Cereal Chem.70, $101-104$.

Rout, G.R., Senapati, S.K., Aparajita, S., and Palai, S.K. (2009). Studies on genetic identification and genetic fidelity of cultivated banana using ISSR markers. Plant Omics J. 2(6), 250 - 258.

Sadia, M., Malik, S.A., Rabbani, M.A. and Peaece, S.R. (2009). Electrphoretic characterization and the relationship between some brassica species. Electron. J. Biol. 5, 14.

Shah, S.M.A., Rahman, H-U., Abbasi, F.M., Rabbani, M.A., Khan, I.A., Shinwari, Z.K. and Shah, Z. (2011). Interspecific variation of total seed protein in wild rice germplasm using SDS-PAGE. Pak. J. Bot. 43, 2147 - 2152.

Shewry, P.R. and Halford, N.G. (2002). Cereal seed storage proteins: structures, properties and role in grain utilization. J. Expt. Bot. 53, 947 - 958.

Shotwell, M.A. and Larkins, B.A. (1989). The biochemistry and molecular biology of seed storage proteins. The Biochemistry of Plants: a Comprehensive Treatise, 15, 297 345.

Song,T.M., Zheng, D.H. and Liu, Y. (1996). Identification of corn varieties using lactate polyacrylamide gel electrophoresis of seed albumins and globulines. Acta Bot Sin. $38(8), 599-604$

Takaiwa, F., Ogawa, M. and Okita, T.W. (1999). Rice glutelins. In: Shewry P R, Casey R. Seed Proteins. Norwell MA, USA: Kluwer Academic Publishers, 1999.

Wei-dong, J., Na, L. and De-lin, H. (2006). Genetic diversity of seed storage proteins in different ecotype varieties of japonica rice and its application. Rice Sci., 13, 85 - 92. accessed on http://www.ricesci.cn; www.ricescience.org

Yang, T.Y., Shen, Y.H., Huang, X.G., He, J.H. and Wu, G.Z. (2005). Identification of genetic diversity in the foxtail millet (Setaria italic L. Beauv.) by SDS-PAGE. Acta Agron Sin. 131(1), $131-133$.

Yu, C.M. and Chen, P.D. (2003). Study on common wheat (T. aestlvum L.) germplasm for waxy protein. J Nanjing Agric Univ. 26 (3): 1-6. (in Chinese with English abstract). 